\title{
As representações sociais da soropositividade e sua relação com a observância terapêutica
}

\author{
Social representations of seropositivity \\ and treatment adherence
}

Gisele Pereira Cardoso 1

Angela Arruda 2

\footnotetext{
1 Programa de Aids/ Serviço de Doenças Infecciosas e Parasitárias do Hospital Universitário Clementino Fraga Filho. Av. Brigadeiro Trompowsky, s/n, 5o andar, Ilha do Fundão, 21941590, Rio de Janeiro RJ. gisela@hucff.ufrj.br 2 Instituto de Psicologia e Núcleo de Estudos e Saúde Coletiva da Universidade Federal do Rio de Janeiro.
}

Abstract Adherence to anti-retroviral therapy (ART) is essential for therapeutic success of HIV infection. Due to the complexity of this theme we consider interesting to analyse it from social representation (SR) theory. Our goal in this study was to outline the processes that give birth to social representations (SR) of seropositivity on HIV/ AIDS patients who may adhere or not to antiretroviral treatment (ART). An exploratory research using observation techniques and a structured interview with 16 men and 16 women who adhered and did not adhere to ART was made. The data was submitted to a categorial content analysis (Bardin). The results showed that adherent patients associate seropositivity to a new condition where medications appear to be included. The pills are objectified as destroying HIV virus and an anchorage on the scientific knowledge is identified. For non-adherents seropositivity is a menace. Denial does not allow an anchorage on scientific knowledge. ART is objectified as causing a disease. As a conclusion we can affirm that while to the adherent patients the SR of the disease and the ART appear as an articulated knowledge system, to the non-adherent the social representations are still being elaborated.

Key words Social representations, HIV/AIDS, Adherence, Seropositivity
Resumo A observância ou adesão terapêutica aos anti-retrovirais (ARV) é fundamental para o sucesso a longo prazo do tratamento para a infecção pelo HIV. Devido à complexidade deste tema consideramos interessante analisá-lo à luz da teoria das representações sociais (RS). Deste modo, procuramos traçar o processo de construção das RS da soropositividade em pacientes com HIV/Aids que aderem e não aderem à terapia $A R V$. Realizamos um estudo exploratório através de técnicas observacionais e entrevistas com roteiro estruturado com 16 homens e 16 mulheres, aderentes e não aderentes. Os dados foram submetidos à análise de conteúdo categorial. Os resultados mostraram que para os aderentes, a soropositividade aparece associada a uma nova normatividade (tomar remédios). O remédio é objetivado destruindo o vírus e existe a ancoragem no saber científico. Para os não aderentes, a soropositividade é uma vivência ameaçadora. O uso da negação impede a ancoragem no saber científico. Os remédios tornam-se a objetivação da doença. Como conclusão, podemos afirmar que, enquanto nos pacientes aderentes observamos RS bem estruturadas da doença e do tratamento ARV, nos $n a \tilde{o}$ aderentes tais $R S$ parecem ainda estar em construção.

Palavras-chave Representação social, HIV/Aids, Adesão, Soropositividade 


\section{Introdução: a observância terapêutica}

Tendo em vista a complexidade do tema relacionado à adesão a tratamento, também chamada observância terapêutica, consideramos interessante analisá-lo a partir da teoria das representações sociais. A adesão é uma das questões mais importantes atualmente quando lidamos com pacientes infectados pelo HIV, pois dela depende o sucesso terapêutico do tratamento. Com a introdução da terapia anti-retroviral (ARV) combinada, a partir de 1996, houve uma expressiva redução na morbi-mortalidade relacionada à Aids, que passou a ser vista como uma doença de caráter evolutivo crônico.

A adesão a tratamento (Ministério da Saúde, 1996) é definida como o estabelecimento de uma atividade conjunta na qual o paciente não apenas obedece a orientação médica, mas entende, concorda e segue a prescrição recomendada pelo seu médico. Qual seria o parâmetro de uma boa adesão a tratamento ARV?

Sabe-se que $81 \%$ de pacientes que tomam $95 \%$ ou mais das cápsulas prescritas conseguem manter a carga viral indetectável num período de seis meses (Paterson et. al., 1999). Entre os estudos empíricos sobre fatores intervenientes na observância terapêutica, aqueles que enfatizam a inserção psicossociológica do fenômeno da adesão terapêutica ainda são pouco freqüentes (Homedes \& Ugalde, 1994; Tunala et al. 2000). No Brasil, um estudo epidemiológico entre usuários soropositivos de ambulatórios do sistema público de saúde do Estado de São Paulo (Nemes, 2000) mostrou uma prevalência da adesão de $69 \%$. No mesmo trabalho, observou-se que a história dos aderentes é uma história de superação de dificuldades relacionadas, sobretudo, à adaptação da medicação ao estilo de vida, às questões vinculadas ao estigma da doença e às crenças negativas sobre os medicamentos. Estas questões possuiriam um papel mais importante na adesão do que as dificuldades ligadas diretamente às drogas prescritas (quantidade e tipo de comprimidos, restrições alimentares, horários, etc.). A necessidade de aceitação da doença e de se estabelecer uma relação de confiança com o médico e com a equipe de saúde, por exemplo, são fatores a serem considerados.

A observância terapêutica, portanto, é um fenômeno complexo que não pode ser reduzido a aspectos da lógica racional, devendo ser consideradas as profundas influências de natureza sociocultural. Por isso, e pela sua já citada relevância, achamos adequado analisá-la à luz da teoria das representações sociais. O objeto de nossa pesquisa é a representação social da soropositividade, visando: 1) conhecer as representações sociais da soropositividade para os pacientes infectados pelo HIV, e 2) discutir o impacto destas na adesão ou não-adesão à terapia ARV.

\section{A abordagem teórica: a teoria das representações sociais}

A Representação Social (RS) é definida como uma forma de conhecimento do "senso comum”. Ela está diretamente relacionada à maneira como as pessoas interpretam ou traduzem os conhecimentos veiculados socialmente. O processo de assimilação do conhecimento é sempre ativo, já que as pessoas entendem e introjetam as informações de acordo com os referenciais que possuem: os indivíduos vão reelaborar o saber científico segundo sua própria "conveniência", ou seja, de acordo com os meios e recursos que têm (Moscovici, 1978).

Três propriedades principais caracterizam as representações sociais:

1) elas são socialmente elaboradas e compartilhadas;

2) elas têm uma função prática de organizar e estruturar o meio circundante;

3) elas distinguem um grupo, dando-lhe um sentido de identidade, na medida em que há uma construção da realidade que é comum a um segmento social.

Jodelet (1988) afirma que as pessoas constroem RS como uma forma de dominar, compreender e explicar os fatos e as idéias que preenchem o universo da vida. Este tipo de conhecimento prático dá sentido à realidade cotidiana. Isto pode ser captado nos processos de formação das RS que são a ancoragem e a objetivação. Na ancoragem, a representação vai buscar a matriz onde se inserir, entendendo-se por matriz o sistema de pensamento social preexistente que dá sentido à representação. Isto é observado ao vermos como as pessoas associam a Aids com as pragas e pestes que ocorreram ao longo da história. Já a objetivação concretizaria em imagens aquilo que é abstrato e distante. Seria a transformação dos vírus HIV na imagem de um "exército devorador" do sistema imunológico ou então a localização nos "grupos homossexuais" da responsabilidade pela epidemia. 
Do ponto de vista formal, a estrutura da RS tem sempre três dimensões: o conteúdo da informação (o grau de conhecimento) relacionado com o objeto social, o campo da representação ou as imagens que a RS suscita nos modelos sociais, e a atitude ou a orientação de um grupo em relação ao objeto da RS. É esta tridimensionalidade que lhe dá sustentação em termos de consistência representativa e importância social.

Há que se ressaltar que a RS se forma com o objetivo de dar um sentido para aquilo que é estranho e novo. A doença é quase sempre uma ameaça na vida das pessoas. Ao darmos um sentido para ela, ao representarmo-la dentro de nós, tornamo-la não só mais próxima e familiar, mas também mais compreensível em nosso universo social.

Quando nos propomos a estudar as RS da soropositividade para os pacientes com HIV e sua repercussão nas condutas de observância a tratamento, estamos procurando entender a tradução que os pacientes fazem de sua doença, da informação médica que recebem, do impacto destes conteúdos na condução de seus tratamentos. Para propormos mudanças nas suas condutas (aderir ao tratamento) precisamos entender o que influencia suas ações, que representações estão embutidas em suas condutas. Todo objeto novo (o tratamento ARV, aderir ou não aderir às práticas medicamentosas) partiria do preexistente (representação sobre a doença, sobre o tratamento, entre outras coisas) e do esperado (melhorar, não melhorar, ficar igual). Recorre-se assim, simultaneamente, ao contexto imediato, ao passado e à expectativa de futuro (Arruda, 2002).

\section{Escolhas metodológicas}

Realizamos um estudo exploratório cujas etapas foram: 1) técnicas de observação de campo (rotina do paciente na instituição: idas à farmácia, freqüência das consultas médicas, etc.); 2) análise do banco de dados da farmácia (quantidade de pacientes inscritos para retirada de ARV, freqüência de retirada, sexo e faixa etária dos pacientes que fazem uso de ARV);3) construção do roteiro preliminar da entrevista; 4) testagem do roteiro em campo; 5) elaboração do roteiro estruturado da entrevista.

A partir de um universo de 1.300 pacientes inscritos para retirada de medicações na farmácia de um hospital universitário do Rio de
Janeiro, foram escolhidos 32 pacientes de acordo com os critérios de sexo, faixa etária e adesão e não-adesão ao tratamento ARV. Esses 32 pacientes estavam divididos em dois grupos: 16 que observavam as práticas de adesão e 16 que não as observavam, cada um subdividido igualmente entre homens e mulheres. Os pacientes foram selecionados a partir da listagem da farmácia do hospital (onde constava autorização ou não para contato) ou mediante encaminhamento de seus respectivos médicos assistentes. Consideramos que por se tratar de um estudo predominantemente de cunho qualitativo, que visava conhecer o sentido das representações sociais e seus modos de elaboração para os pacientes com HIV, o número de 32 pacientes seria representativo para a construção de nossa amostra.

A faixa etária selecionada foi de 30-39 anos por ser a predominante entre nossos pacientes (39\%). O critério utilizado para adesão ao tratamento foi o critério da farmácia do hospital: o paciente que retira regularmente (todo mês) a medicação é considerado aderente, o que não o faz há mais de 3 meses entra na categoria de abandono de tratamento. A pesquisa confirmaria as nuances apontadas na literatura quanto à noção de adesão, problematizando este critério.

Com relação ao nível de escolaridade, ambos os grupos estavam bastante parecidos. Entre os pacientes aderentes constavam oito pessoas com ensino básico incompleto, quatro que concluíram o ensino básico, dois o ensino médio e dois cursaram faculdade. No grupo dos não aderentes, dez tinham o ensino básico incompleto, três o ensino básico completo, dois o ensino médio e um o nível universitário.

Utilizamos uma entrevista composta de associações livres e 24 perguntas abertas, destinada a explorar duas questões principais: a relação do sujeito com sua condição de soropositivo e com seu tratamento ARV. Antes do início da entrevista algumas perguntas sobre dados sociodemográficos dos pacientes foram realizadas. As entrevistas foram gravadas e transcritas e duraram, em média, 40-45 minutos.

Após a transcrição das fitas, partimos para a leitura "flutuante" das mesmas e em seguida para a análise de conteúdo categorial de acordo com Bardin (1977), na qual categorizamos as falas dos pacientes através de um recorte dos temas e em seguida tabulamos a freqüência com que aparecem. Foi igualmente feita uma análise de co-ocorrência. 


\section{Resultados}

\section{Análise das respostas}

Antes de analisar o conteúdo das respostas, ou seja, de adentrarmos no campo das RS propriamente ditas, durante a transcrição das entrevistas já foi possível observar diferenças no grau de conhecimento e na atitude dos dois grupos estudados. Enquanto no grupo dos aderentes observamos um maior grau de informação, de apoio e acolhimento familiar e social, uma maior importância da relação com o médico assistente e um comprometimento importante com o tratamento $\mathrm{ARV}$, nos não aderentes predominou uma atitude mais distante e de evitação. Chamou a atenção, em várias ocasiões, a pouca familiaridade tanto com a doença quanto com o tratamento ARV. As entrevistas com os pacientes não aderentes foram mais difíceis de transcrever, pois freqüentemente caíam em contradição, mostrando-se por momentos bastante confusos em suas respostas. Comparamos este resultado com o nível de escolaridade de ambos os grupos. Observamos que apesar de haver mais pacientes não aderentes (dois) com o ensino básico incompleto do que pacientes aderentes, o conteúdo das falas e a atitude dos pacientes não aderentes em relação ao tratamento não variou em função do nível de escolaridade dentro do próprio grupo.

A análise da primeira pergunta do roteiro (Quando eu falo a palavra soropositivo para você, o que vem na sua cabeça?) já permitiu vislumbrar diferenças expressivas entre os pacientes aderentes e os não aderentes a tratamento no processo de construção da RS. Para os pacientes aderentes existiriam dois momentos: o de antes como tendo sido algo difícil de aceitar, associado à morte, e o de depois sendo vivido como uma nova condição, mais adaptada à nova situação. Um paciente aderente descreve o ser soropositivo como tendo uma "bomba-relógio" dentro de si. O tratamento ARV aparece mencionado por alguns dos pacientes aderentes já na associação livre. Para os não aderentes predomina um só momento extremamente perturbador. A impressão que dá é a de que o paciente não aderente ainda está sob o impacto do diagnóstico de HIV ("difícil" / "morte" / "doença ruim").

Em relação à percepção de risco em contrair o HIV, não observamos uma diferença expressiva entre aderentes e não aderentes ao tra- tamento ARV, mas sim entre gêneros. Enquanto o homem percebe o risco e acredita que já se contaminou seja por "descuido", por um "coquetel de pecados" (Joffe, 1995) ou por uma crença na própria imunidade, para a mulher este risco está ausente de seu universo. Nas mulheres não encontramos esta responsabilização, mas sim respostas de cunho fatalista ("tem que acontecer" / "deve ter um porquê na vida das pessoas"). Observamos como uma dificuldade de serem sujeitas de sua própria vida, de sua própria história.

Em relação ao fato de terem compartilhado do diagnóstico com alguém de seu meio familiar e/ou social, todos os pacientes aderentes, com exceção de um, compartilharam. Chama a atenção que todos os homens receberam algum tipo de apoio e acolhimento, sendo que nas mulheres aderentes somente um terço relatou ter tido apoio e não recriminação. No caso dos pacientes não aderentes, todos compartilharam, mas o apoio aparece como sendo algo bem mais restrito. Apenas a metade dos homens relata ter tido apoio, sendo esta percentagem ainda menor entre as mulheres não aderentes $(25 \%)$.

Outro dado extremamente interessante relacionado também à questão de gênero foi quanto à qual seria a maior preocupação em ser soropositivo. Para os homens, tanto aderentes quanto não aderentes, a preocupação está voltada para si mesmos (não adoecer, não morrer, tomar os remédios). Nas mulheres, predomina uma preocupação em relação aos outros e ao futuro dos mesmos, mesmo entre aquelas que não têm parceiro e/ou filhos. Isto reforça o que se considera ser o papel das mulheres em nossa sociedade: cuidar, olhar e proteger aqueles que a rodeiam.

Em relação às mudanças ocorridas na vida a partir da soropositividade, nos homens de um modo geral, tanto aderentes quanto não aderentes, identificamos processos semelhantes. A soropositividade impõe perdas importantes (amigos/emprego/planos), mas ao mesmo tempo traz mudanças internas de cunho positivo (novos valores/ganhos religiosos). Os homens não aderentes sinalizam que, apesar de não tomarem remédios, conseguiram sair do mundo das drogas ou colocar um freio sobre o uso descontrolado de álcool e/ou drogas. Nas mulheres, não haveria diferença nos dois grupos de aderentes e não aderentes ao tratamento. Todas relatam perdas (sexuais/saúde) e mudanças internas predominantemente negativas 
(perda da alegria/sentimento de estranhe$\mathrm{za} /$ preconceito/medo).

E como é viver a soropositividade no dia a dia? Para os pacientes aderentes a soropositividade aparece fortemente associada a "tomar remédios", ou seja, percebemos o ingresso numa nova normatividade (Canguilhem, 1978). Observamos como os pacientes aderentes se utilizam de estratégias para lidar com as dificuldades impostas pelos remédios (uso de portacomprimidos e garrafas de água dentro da bolsa ou da sacola, ao sair de casa, entre outras) e com as limitações que a soropositividade acarreta (vida sexual/vida afetiva principalmente). Além de tomar os remédios, aparece associado um "coquetel de cuidados" que inclui uma vida regrada, pensamentos positivos, apoio da família e do médico. Nos não aderentes predomina a vivência da soropositividade como sendo algo muito perturbador no dia a dia. Muitos preferem dissociar e negar que sejam soropositivos ("é uma vida normal" / "é como se não fosse") para continuar adiante. Não desenvolvem, assim, estratégias para lidar com as dificuldades impostas pelos remédios como com as limitações acarretadas pela soropositividade. As mulheres não aderentes chegam a falar em determinados cuidados que são necessários ("se alimentar bem" / "atitude positiva" / "evitar abusos"), mas os remédios não estão incluídos no ser soropositivo.

Os motivos principais pelos quais os pacientes como um todo relatam haver abandonado seu tratamento ARV são: os efeitos colaterais (principal motivo), as perdas afetivas/problemas em família e o conflito entre tomar remédios e hábitos de vida. Mais da metade dos pacientes aderentes já foi não aderente em algum momento, principalmente por conta dos efeitos colaterais das drogas ou quando o tratamento foi algo imposto pelo médico.

$\mathrm{O}$ tratamento ARV é visto de maneira bastante diferente por ambos os grupos. Enquanto que para os pacientes aderentes ele destrói e transforma tudo para melhor (ele é muito forte positivamente); nos não aderentes, ele faz mal, piorando a qualidade de vida (ele é muito forte negativamente). Vários pacientes não aderentes duvidam dos efeitos benéficos do tratamento ARV.

Vamos observando como os pacientes aderentes têm uma familiaridade com sua doença e seu tratamento. Existe a objetivação da ação do medicamento destruindo o vírus, o que leva a uma clara procura de informações e a uma participação ativa no tratamento. Chama a atenção a naturalidade com que falam em carga viral, contagem de CD4, efeitos colaterais, etc. Apesar de nem sempre se lembrarem dos nomes dos remédios, eles denotam conhecer o que se passa com eles. Este processo, que na teoria das RS chamamos de ancoragem, ocorre como uma forma de se obter um controle sobre o que acontece com o próprio sujeito. $\mathrm{O}$ paciente incorpora, então, parte da linguagem do universo reificado da ciência, que ajuda, transmite segurança. Junto com a novidade da doença, vêm também os remédios (ARV) e um novo mundo. Aceder ao universo científico aparece como forma de nomear e controlar o que é vivido como tão incontrolável. Assim, a incorporação do vocabulário científico seria um aspecto da ancoragem da soropositividade. Para estes pacientes a medicação é associada com a esperança e a possibilidade de um prolongamento da vida. Nos não aderentes há uma aparente pouca familiaridade com a doença. Não há uma associação do medicamento com a esperança ou com o prolongamento da vida. Ao contrário, existe a imagem do medicamento provocando uma outra doença, o que leva a uma atitude de afastamento e de evitação em relação ao tratamento. Não observamos uma ancoragem no pensamento científico. Tomar remédio seria perder o controle sobre o próprio corpo em função dos efeitos colaterais.

A relação com a pessoa do médico também mostrou ter um sentido bastante diferente para ambos os grupos de pacientes. Enquanto que para os pacientes aderentes é nítida a presença de um forte vínculo afetivo, para os pacientes não aderentes o que prevalece é uma relação vista de maneira bastante conflituosa. Para os pacientes aderentes o médico é descrito como um irmão, um amigo, alguém com quem se pode compartilhar todos os sentimentos. A atitude destes pacientes é também bastante participativa. Já a maioria dos pacientes não aderentes relata não conversar com seus médicos. Alguns dos pacientes não aderentes relataram perceber um esforço por parte de seus respectivos médicos em querer uma aproximação com eles, mas ela é neutralizada por uma falta de iniciativa por parte deles próprios em aproximar-se de seus médicos.

O último ponto investigado na entrevista foi a expectativa de cura. Para ambos os grupos de pacientes há uma crença generalizada na cura da Aids, porém a forma como lidam com ela é completamente antagônica. Os pacientes ade- 
rentes sabem que no presente ela não existe, contudo, acreditam que a cura virá no futuro, através da mão do homem ("a medicina irá encontrar a cura no futuro"). Enquanto a cura não chega existiria uma "cura paliativa", que inclui, além de tomar remédios, uma vida regrada e saudável. Para os pacientes não aderentes não existiria esta cura paliativa. A cura virá pelas mãos de Deus, através da fé ou do milagre. A figura do homem não aparece assim participando deste processo. Está tudo nas mãos de outro, de Deus.

\section{Análise das co-ocorrências}

Procedemos a uma análise de co-ocorrência cujo resultado passamos a descrever.

\section{RS da soropositividade para os homens aderentes}

Entre os homens aderentes percebemos o predomínio de dois padrões: a soropositividade como normal e a soropositividade como difícil (Figura 1). No primeiro padrão observamos o ingresso numa nova normatividade, no segundo predomina o aspecto mais negativo.

Quase a metade dos homens aderentes se insere no primeiro padrão. Contudo, ambos os esquemas têm muito em comum. A teoria da responsabilidade aparece de forma clara e explícita nos dois. O tratamento é visto de maneira realística, pois é "bom e ótimo" para a maioria, apesar de também fazer mal, pois existem os efeitos colaterais, e são "fortes". Ou então, o tratamento é "ruim", mas "ajuda/levanta". A existência de uma "cura paliativa" mostra que também é importante lançar mão de outros recursos, como já vimos anteriormente (atitude positiva, vida regrada). Tanto a vivência da soropositividade, como a relação com o tratamento ARV aparecem muito bem definidos e marcados.

\section{RS da soropositividade para as mulheres aderentes}

Para a maioria das mulheres a responsabilidade de ser soropositiva não é dela, mas sim do outro. Isto apareceu nas entrevistas pelas reações de susto, o choque-duplo (saber que o marido estava contaminado e que elas também estavam).

As co-ocorrências indicaram três padrões de resposta femininas: a soropositividade como fatalidade, como perturbadora e como incorporada à vida (Figura 2).

\section{Figura 1}

Padrões de respostas nos homens aderentes.

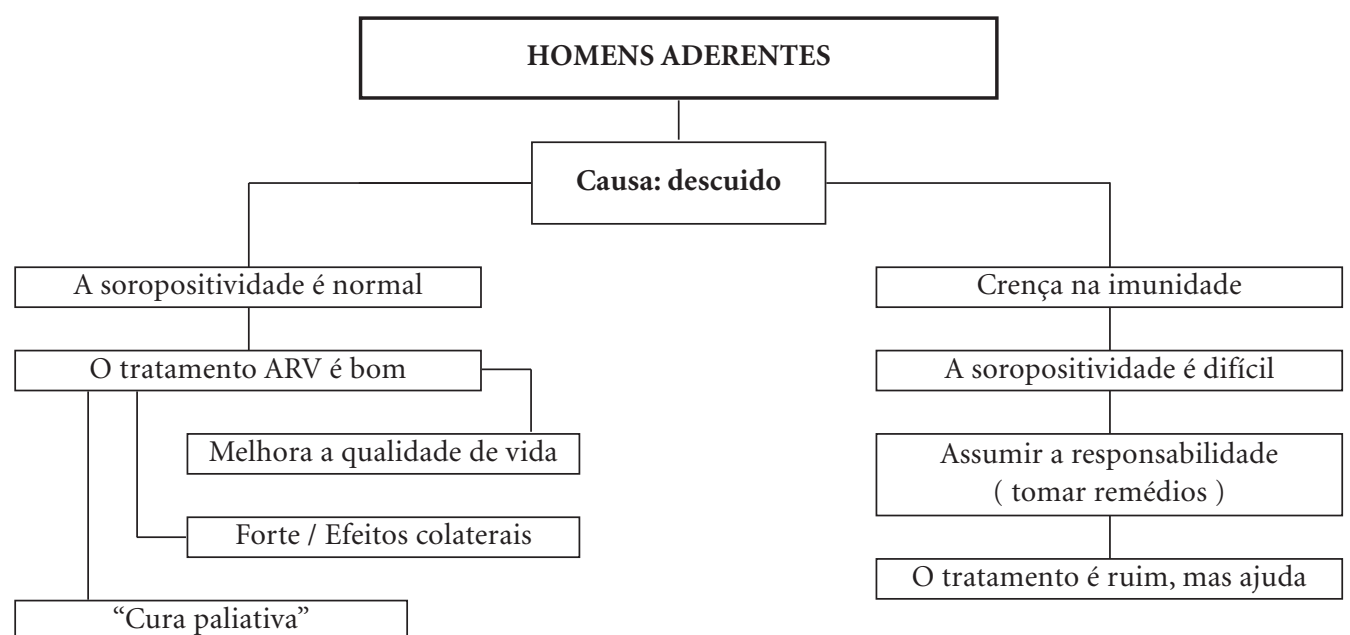


Figura 2

Padrões de respostas nas mulheres aderentes.

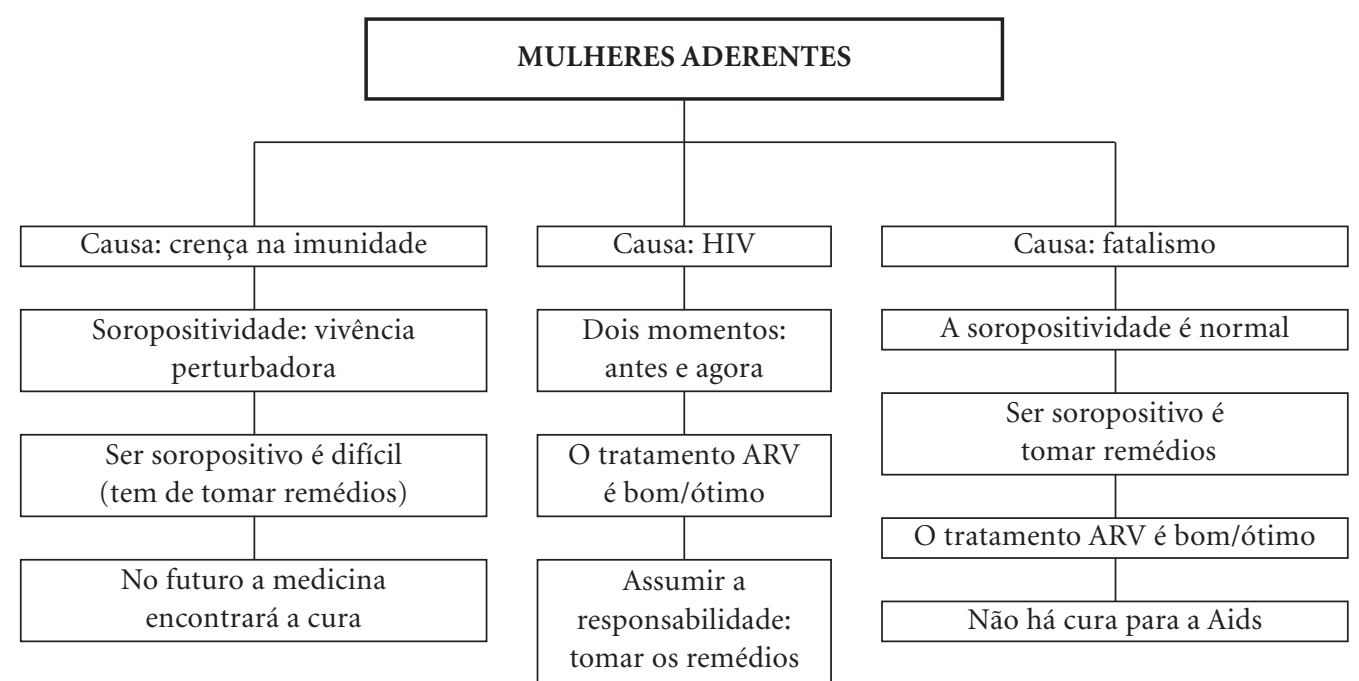

O padrão da fatalidade é manifestado por três mulheres: é ela a causa da soropositividade. Esta representação incorpora a soropositividade como normal, e não vê cura para a Aids; há uma espécie de submissão relativa ao destino, sem abrir mão de gerenciar o tratamento. O padrão de crença na imunidade reforça que a responsabilidade de ser soropositiva não é dela (vivência perturbadora), e a vida é difícil. Contudo, consegue tomar os remédios e há esperança de que no futuro a medicina encontrará a cura. O padrão dos dois momentos (antes e agora) explicita o processo de elaboração, de aceitação de uma nova normalidade/normatividade. Chama a atenção o aspecto positivo e mais determinado: assumir a responsabilidade/tomar remédios.

A partir destas co-ocorrências, e tomando como base a totalidade das respostas dadas nas entrevistas, poderíamos afirmar que para estes pacientes soropositivos aderentes a Aids se torna uma "doença-ofício" (Herzlich, 1992): aquela que se transforma em situação de aprendizagem, e o doente, em vez de ter um caráter meramente passivo, se torna ativo, dedicado a seu novo papel, lutando. A reação do paciente aderente, como vemos, é de suportar os efeitos colaterais, participar do tratamento (perguntan- do, lendo, informando-se), reaprendendo a viver. Assim, consegue colocar-se no papel de doente, aceitando as condições impostas pela doença e preservando sua identidade.

\section{RS da soropositividade para os homens não aderentes}

Nos homens observamos o predomínio de dois padrões, como pode ser verificado na figura 3.

Nestes dois padrões masculinos predominantes observamos duas tendências: na primeira, uma forte negação e, na segunda, o que aparece é um tom extremamente sombrio, depressivo. Não há alusão à questão da responsabilidade. Apesar de o tratamento ser mencionado, não há qualquer referência à necessidade de tomar remédio.

\section{RS da soropositividade para as mulheres não aderentes}

Chama a atenção a "vivência perturbadora" da soropositividade como algo que marca e define as mulheres não aderentes, e a crença numa cura que vem da fé ou do milagre (Figura 4). Mais uma vez, observamos como a questão 
Figura 3

Padrões de respostas nos homens não aderentes.

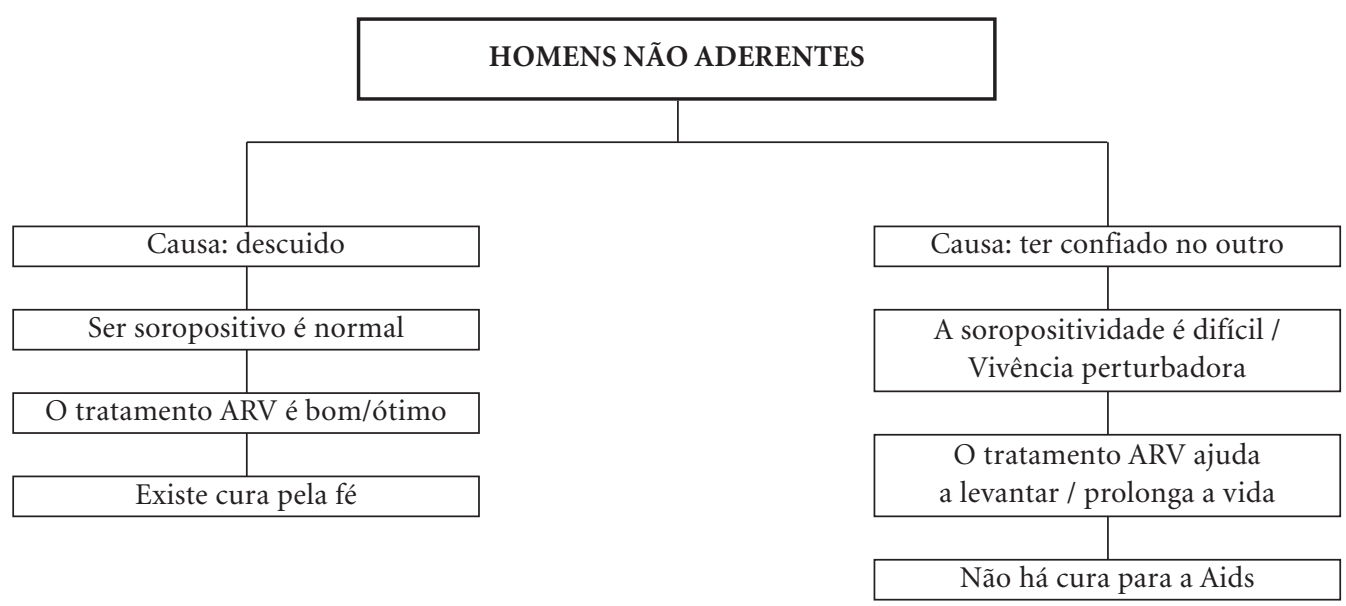

\section{Figura 4}

Padrões de respostas nas mulheres não aderentes.

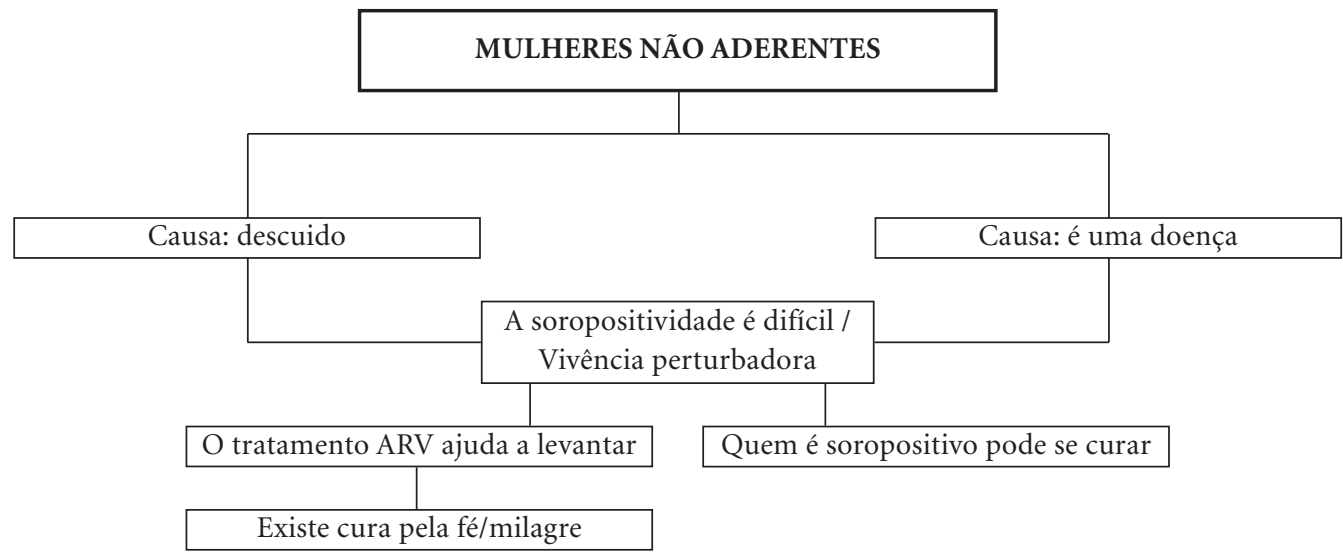

da auto-responsabilidade não faz parte da vivência de ser soropositivo do paciente não aderente. As descrições do tratamento (o tratamento ARV ajuda a levantar), ao mesmo tempo em que parecem corretas, são também uma resposta padrão, estando deslocadas do restante da conduta desses pacientes.
Percebemos que existem pontos importantes em comum entre as mulheres e os homens não aderentes. Estes pontos são exatamente a "vivência perturbadora" e a questão da "desinformação"/“descuido” originando o HIV. A auto-responsabilidade não aparece, nem em relação ao ser soropositivo nem em relação aos re- 
médios. A vivência da doença é de algo extremamente mobilizante. De acordo com Herzlich (1992), poderíamos denominar esta forma de vínculo com a doença de "destruidora". A doença é vista como uma forma de desvio: não logrando se inserir numa nova normatividade, como vimos nos aderentes, o doente se sente diminuído (sentimentos depressivos). A reação é de negação ("é normal"), quando sabemos que ele não se trata, ou então, mágica, quando responde que "tem cura". De acordo com esta autora, a recusa em enfrentar a doença seria uma maneira de triunfar sobre ela, pois já que ela não existe, não é preciso submeter-se a ela. A doença é vivida como uma intensa ameaça à própria identidade que precisa persistir como a de uma pessoa sadia, não precisando, então, nem de remédios nem de tratamento.

\section{Análise das co-ocorrências entre aderentes e não aderentes}

A partir de todas estas informações, podemos afirmar que os padrões de co-ocorrências entre os pacientes aderentes e os não aderentes são completamente diversos. Enquanto os aderentes introjetam/internalizam/convivem com a soropositividade, os não aderentes excluem/ negam/condenam. Predomina neles a vivência perturbadora, o sombrio, que já predominou nos aderentes num primeiro momento. Percebemos que nos pacientes aderentes o tratamento faz parte do ser soropositivo. Os remédios aparecem objetivados como fortes, tanto no aspecto positivo ("ajuda" / "levanta") quanto no negativo (efeitos colaterais: "a pele muda", "dá reações estranhas no organismo"). Contudo, os benefícios dos remédios seriam mais valorizados do que os negativos. Representar implica necessariamente recriar, reconstituir. Os pacientes aderentes criam um terreno de ancoragem para dominar a angústia gerada pela soropositividade. Eles vão em busca de informações, eles passam a dominar uma linguagem que não é a do mundo deles (carga viral, contagem de $\mathrm{CD} 4$, entre outros) que lhes permite reconstruir a realidade. Observamos, assim, nesta análise, que as RS da soropositividade e do tratamento ARV aparecem como um sistema articulado de saber em que se misturam as dimensões figurativas (imagens) e conceituais (construções teóricas) de sua estrutura.

A representação da soropositividade para os pacientes não aderentes pareceria seguir outro caminho. Na medida em que esta vivência é tão angustiante e perturbadora ela não teria onde se ancorar. O que estaria na base seria a negação (não existe a doença nem a necessidade de tomar remédios) e a dissociação (a vida passa a ser normal). Morant e Rose (1998) ao estudarem o tema da loucura à luz das RS, descrevem que a mesma resiste a uma classificação, exatamente por seu caráter angustiante e ameaçador. Ora ela é vista como algo perigoso, ao mesmo tempo em que pode também ser controlada e dominada. Sua ancoragem seria instável e provisória, tal como estamos vendo que os pacientes não aderentes percebem e vivenciam a soropositividade. Aquilo que não é familiar, ou seja, a doença, continua sendo estranha. A premissa da RS de que uma de suas funções seria a de tornar familiar o não familiar não se daria aqui da maneira esperada. $\mathrm{O}$ processo é interrompido abruptamente. Questionamos assim, se no caso dos pacientes não aderentes existiria ou não uma representação social da soropositividade ou, se com os recursos técnicos que utilizamos, não foi possível delineá-la de uma forma mais clara.

$\mathrm{O}$ tratamento $\mathrm{ARV}$, para estes pacientes não aderentes, aparece como "uma bomba que jogam no organismo". Os remédios "entalam", "intoxicam", "sufocam", "maltratam". Na análise das co-ocorrências, a descrição do tratamento aparece muito esvaziada (há poucas co-ocorrências) e quando aparecem, são estereotipadas e dissociadas: "bom" / "ótimo", "ajuda" / "levanta”.

Percebemos assim que aquilo que gera excessiva ansiedade dificulta a estruturação da representação. Enquanto que nos pacientes aderentes observamos a presença de representações muito bem estruturadas tanto da doença quanto do tratamento $\mathrm{ARV}$, nos pacientes não aderentes questionamos, em alguns momentos, se tais representações realmente chegam a existir, já que o mecanismo que está na base do funcionamento destes pacientes é a negação que impediria qualquer processo elaborativo mais complexo.

Assim sendo, o sentido atribuído à soropositividade pelos pacientes é completamente diverso. Encontramos as diferenças mais expressivas entre os grupos dos pacientes (aderentes e não aderentes), na questão de poder ser um sujeito ativo, protagonista de sua própria história no caso dos aderentes; e passivo, no caso dos não aderentes. $O$ sentido da responsabilidade, então, é completamente diferente, tanto na relação consigo mesmo (poder encontrar recursos e caminhos para se adaptar à nova condição), 
quanto na relação com o tratamento (tomar ou não tomar os remédios) e com o futuro (crença na medicina ou no milagre como solução).

Existem algumas diferenças que passam pela questão de gênero. Para as mulheres, tanto aderentes quanto não aderentes, a visão submissa, fatalista da soropositividade é marcante. A responsabilidade de ser soropositiva não é delas, mas do outro que as colocou nesta condição. Contudo, a mulher soropositiva aderente consegue sair desse lugar passivo e assumir a responsabilidade de se tratar, enquanto que a não aderente continua aprisionada.

\section{Conclusões e sugestões}

$\mathrm{Na}$ análise que empreendemos percebemos como os saberes dos sujeitos que entrevistamos são construídos numa rede de relações complexas, na qual estão envolvidos os níveis individuais e coletivos, em um contexto familiar, histórico e sociocultural. A complexidade subjacente às condutas e decisões mostra como a racionalidade não só não é uniforme, como tampouco é o único parâmetro do agir (Madeira, 1998). As razões pelas quais os indivíduos vão seguir ou não as condutas de observância a tratamento vão depender de inúmeros fatores (esquema terapêutico, momento de evolução da doença, tipo de doença, grau de apoio familiar e social, etc.) e entre eles, também podemos incluir a representação social que a soropositividade tem para estes sujeitos.

Observamos na nossa análise como as falas e as condutas dos pacientes foram reveladoras de seus sentimentos e de sua relação com a doença e seu tratamento. Esta análise nos apontou o caminho para a organização das representações. Assim, percebemos como para o paciente aderente, a atitude de enfrentar a doença favorece a adesão. Os pacientes aderentes são ativos e participam da causa pela qual lutam. Eles exercitam a adesão no dia-a-dia, criando um terreno de ancoragem para dominar a angústia gerada pela soropositividade: procuram informações, incorporam uma nova linguagem vinda do mundo médico/científico). O sistema de representação da soropositividade aparece bem articulado e estruturado. Existem causas para o ser soropositivo: o "descuido", o "fatalismo", a "crença na imunidade". A soropositividade é uma nova condição à qual se adapta, imposta por uma nova "normatividade" (“tomar remédios"). É preciso ter estra- tégias para lidar com as dificuldades impostas por esta situação ("Eu boto pra fora, mas eu boto pra dentro"). Aqueles que conseguem adaptar-se a esta nova regra conseguiriam "ter uma vida normal". Para isto, seria imprescindível "reaprender a viver", ou seja, a participação do próprio indivíduo como um sujeito ativo. Apesar de não haver uma cura para a Aids, existe a "cura paliativa" ("pensamento positivo", "vida saudável”) e no futuro, “a medicina encontrará a cura".

A representação do remédio também aparece de maneira marcada. Ele "é forte", mostrando seu lado bom: "ajuda" / "levanta”, e ruim: "tem os efeitos colaterais". Esta representação está inserida na representação da soropositividade, fazendo parte da mesma. Ser soropositivo para o paciente aderente é cuidar-se, é fazer o tratamento ARV. A questão da responsabilidade consigo mesmo é fundamental na condução do tratamento. Existe, assim, a crença no homem como agente de sua própria vida e criador de sua própria história de saúde.

Alguns pontos merecem ser destacados nos relatos dos pacientes aderentes - a importância da relação médico-paciente: o médico é um "parceiro" / "amigo", e o grau de apoio e/ou acolhida, seja por parte dos parceiros/familiares e amigos (principalmente no caso dos homens) e também dos profissionais de saúde.

Outro dado interessante é que mais da metade dos pacientes aderentes já parou o tratamento em algum momento. Os efeitos colaterais e as situações de abuso de drogas/álcool, quando o médico "obrigou" a tomar, desentendimento em família, ruptura de relações, perdas de pessoas queridas, discriminação, são citados como motivos do abandono, mesmo que temporário. Às vezes, pára-se, também, para fazer um teste e depois retorna-se ao tratamento. Contudo, no paciente aderente, o que prevalece como o que precisa ser combatido é a "bomba-relógio” (HIV) que sente que está dentro dele. O tratamento acaba sendo visto, assim, como algo predominantemente "bom" para a maioria.

Em relação aos pacientes não aderentes, não pudemos perceber uma representação da soropositividade tão bem delineada como aparece para os pacientes aderentes. A representação do remédio aparece como a objetivação da doença Aids ("Os remédios são como uma bomba no organismo”), pois o paciente não aderente sente-se doente tomando remédios: ele "entala", "intoxica", "sufoca". O peso dos efeitos colaterais torna o tratamento, ao invés 
de um parceiro da vida, uma ameaça ("Tenho mais medo do remédio do que da doença"). Encontramos nestes pacientes o predomínio de uma intensa vivência perturbadora, um "choque" que paralisa e, portanto, dificulta a adaptação à condição de ser soropositivo. A estratégia defensiva é dissociar e negar parte da realidade. Na medida em que há uma negação, não há uma procura de informações e há uma evitação de contato com tudo que tem relação com a doença e o tratamento (ida às consultas, realização de exames). A recusa em enfrentar a doença seria uma maneira de triunfar sobre ela (Herzlich, 1992), pois não existindo, não é preciso se submeter a ela. A identidade do sujeito permanece como a de uma pessoa sã, não precisando, portanto, nem de tratamento, nem de remédios. A solução ou a "cura" não está nas mãos do homem, como nos pacientes aderentes, mas sim no milagre, em Deus. Ele projeta no outro tanto a culpa quanto a responsabilidade de ser soropositivo

Os motivos pelos quais os pacientes não aderentes alegam terem abandonado o tratamento ARV são: os efeitos colaterais, o fato de não terem conseguido absorção na rede para atendimento após encaminhamento, mau atendimento na instituição, discriminação, "baixo astral", uso de drogas e álcool, sentimento de falta de alguém que os ajude a tomar a medicação. Estes fatores, com certeza, contribuíram e se associaram às dificuldades já existentes no lidar com a condição de ser soropositivo.

Considerando o exposto, fazemos as seguintes sugestões:

1) É extremamente importante perceber qual é o significado da soropositividade para o paciente, qual é o sentido que dá para o estar doente e para precisar dos remédios. Ser soropositivo no paciente aderente, como já vimos, implica aceitar a doença, adaptar-se a uma no- va condição de vida, assumindo a própria responsabilidade no estar doente. $\mathrm{O}$ momento de início do tratamento é, com certeza, um dos mais delicados na relação com a soropositividade, pois mobiliza todo o campo representacional da condição de ser soropositivo (ou seja, o mundo dos sentidos, do desejo e dos afetos que é construído nos contextos socioculturais, políticos e históricos). O paciente precisa estar seguro de que tomar os remédios é o melhor para ele naquele momento e não sentir que o tratamento é algo imposto pelo seu médico.

2) A identificação dos momentos de maior vulnerabilidade para o abandono do tratamento, como podem ser desentendimentos em família, rupturas, perdas de pessoas queridas, vivências de discriminação, são um sinal de alerta. Estas situações podem gerar sentimentos de insegurança, baixa auto-estima, tristeza e desesperança que facilitam a descontinuidade do tratamento.

3) O grau de apoio e acolhimento por parte de parceiros/familiares e amigos é extremamente importante. O paciente necessita de ajuda para tomar os remédios, tanto na lembrança de horários, no apoio afetivo, nas informações que recebe, como na elaboração de estratégias que facilitem sua administração.

4) O papel das instituições de saúde é fundamental para que o paciente se sinta amparado e seguro. Quando o paciente não se sente acolhido pela instituição e compreendido pelos profissionais que o atendem, ele se torna mais vulnerável ao abandono. Três pacientes de nosso grupo de entrevistados se encaixaram neste padrão.

5) As diferenças de gênero existem e é importante levá-las em consideração. A mulher mostra ter menos apoio/acolhimento em seu meio familiar e social, precisando de um auxílio maior dos profissionais especializados. 


\section{Colaboradores}

G Cardoso escreveu este artigo a partir do estudo realizado em sua dissertação de mestrado ("Representações sociais da soropositividade: um estudo a partir das práticas de adesão a tratamento"), defendida no Núcleo de Estudos em Saúde Coletiva (NESC) da UFRJ (agosto de 2002). A Arruda realizou o trabalho de orientação da pesquisa e revisão do texto.

\section{Referências bibliográficas}

Arruda A 2002. Novos significados da saúde e as representações sociais. Cadernos de Saúde Coletiva, 10(2): 215-227.

Bardin L 1977. Análise de conteúdo. Ed. 70, Lisboa.

Brasil 2000. Coordenação Nacional de DST/Aids 2000. Pesquisadora principal: Nemes MIB. Aderência ao tratamento por anti-retrovirais em serviços públicos no estado de São Paulo. Ministério da Saúde, Brasília.

Brasil 1999. Coordenação Nacional de DST/Aids 1999. Conceito e recomendações básicas. Ministério da Saúde, Brasília.

Canguilhem G 1978. O normal e o patológico. Editora Forense-Universitária, Rio de Janeiro.

Herzlich C 1992. La perception quotidienne de la santé et de la maladie. Uwe Flick (org.) Ed. Lítaimattan, Paris.

Homedes N \& Ugalde A 1994. Estúdios sobre el cumplimiento del paciente em paises en desarrollo. Boletin Oficina Sanitária Panamericana 116(6):518-534.

Jodelet D 1998. Representações do contágio e a Aids, pp. 17-45. In D Jodelet \& M Madeira (orgs.). Aids e representações sociais: à busca de sentidos. Editora da Universidade Federal do Rio Grande do Norte (EDUFRN), Natal.
Joffe H 1995. "Eu não, o meu grupo não”: representações sociais transculturais da Aids, pp. 297-322. In P Guareschi \& S Jovchelovitch (orgs.). Textos em representações sociais. Editora Vozes, Petrópolis.

Morant N \& Rose D 1998. Loucura, multiplicidade e alteridade, pp. 129-148. In A Arruda (org.). Representando a alteridade. Editora Vozes, Petrópolis.

Moscovici S 1978. A representação social da psicanálise. Editora Zahar, Rio de Janeiro.

Paterson D, Swindells S \& Mohr J 2000. Adherence to protease inhibitor therapy and outcome inpatient with HIV infection. Annals of Internal Medicine 133:21-30.

Tunala L et al. 2000. Fatores psicossociais que dificultam a adesão das mulheres portadoras do HIV aos cuidados de saúde, pp. 79-114. In PR Teixeira, V Paiva \& E Shimma (orgs.). Tá difícil de engolir: experiências de adesão ao tratamento anti-retroviral em São Paulo. Editora Nepaids, Programa Estadual DST/AIDS-SP, Centro de Referência e Treinamento DST/AIDS-SP, São Paulo.

Artigo apresentado em 20/12/2003

Aprovado em 30/8/2004

Versão final apresentada em 1\%/12/2004 